\title{
Peptide immunoreactive nerves and cells of the guinea pig gall bladder and biliary pathways
}

\author{
W CAI, J GU, W HUANG, G P MCGREGOR, M A GHATEI, \\ S R BLOOM, AND J M POLAK
}

From the Department of Histochemistry and Medicine, Royal Postgraduate Medical School, Hammersmith Hospital, London

SUMMARY Using the methods of immunocytochemistry and radioimmunoassay, five peptides (vasoactive intestinal polypeptide (VIP), substance $P$, somatostatin, met-enkephalin, and bombesin) have been found in the gall bladder and the biliary tracts of guinea pig and each of them possesses a characteristic distribution pattern. Networks of nerves containing each peptide were found in the smooth muscle, around blood vessels and, occasionally, in the lamina propria. The distribution of the peptide immunoreactive nerves in the gall bladder and biliary tract is similar to those found in the gut. Vasoactive intestinal polypeptide $(11 \pm 1.5 \mathrm{pmol} / \mathrm{g}$ in the sphincters, mean \pm SEM) and substance $P(21.5 \pm 1.8 \mathrm{pmol} / \mathrm{g}$ in the common bile duct) were found to be the most abundant peptides and a few VIP and substance $P$ immunoreactive neurones were localised in the ganglionated plexus. Bombesin immunoreactive nerves were mainly seen in the sphincter of Oddi, where the mean concentration of extractable bombesin was $14 \cdot 6 \pm 2$ $\mathrm{pmol} / \mathrm{g}$. Somatostatin immunoreactive mucosal endocrine cells were identified in the epithelium of the common bile duct and the sphincter. The extractable somatostatin in these regions were $76 \pm 19 \mathrm{pmol} / \mathrm{g}$ and $162 \pm 30 \mathrm{pmol} / \mathrm{g}$ respectively.

The gall bladder and the biliary pathways have been known for a long time to be innervated by cholinergic and adrenergic nerves. ${ }^{1-13}$ As these organs are outgrowths of the alimentary canal and the latter is known to contain a large number of peptidergic nerves and peptide containing endocrine cells, ${ }^{14-17}$ one might expect that peptide containing nerves and cells are also present in the gall bladder and the biliary tract. Indeed, it has been recently reported that non-adrenergic, non-cholinergic nerves are present in the gall bladder of the guinea pig $^{11}$ and nerves containing vasoactive intestinal polypeptide (VIP) have been found in both the gall bladder and the sphincter of Oddi in many mammalian species. ${ }^{18} 19$ Nerves containing metenkephalin-like immunoreactivity have been shown in the myenteric plexuses of the gall bladder and the cystic duct in man. ${ }^{20}$ Mucosal endocrine cells containing motilin and substance $P$ have been reported to be present in the bile duct of rabbit. ${ }^{21}$

Address for correspondence: Dr J M Polak. Department of Histochemistry, Royal Postgraduate Medical School, Hammersmith Hospital, Ducane Road, London W12 0HS.

Received for publication 28 February 1983
Information on the detailed distribution and concentration of VIP and met-enkephalin containing nerves in the gall bladder, and the occurrence of nerves and cells containing other peptides, however, has not been available. We therefore investigated the precise distribution of VIP containing nerves and the occurrence of other types of peptide containing nerves and mucosal endocrine cells in the gall bladder and biliary pathways of guinea pig, using the methods of immunocytochemistry and radioimmunoassay.

\section{Methods}

ANIMALS

Twelve adult (body weight 280-350 g) and eight newborn (one to four days) guinea pigs (Dunkin/ Hartley) of both sexes were killed by cervical dislocation and the whole gall bladders, cystic ducts, hepatic ducts, common bile ducts, and the cranial portions of the duodenum were removed immediately after death. The specimens were fixed by immersion in $0.4 \%$ benzoquinone in $0.01 \mathrm{M}$ phosphate buffered saline ( $\mathrm{pH} \mathrm{7.4)}$ (PBS) for 30 
minutes at room temperature. ${ }^{22}$ The samples were then washed in $7 \%$ sucrose in PBS at $4^{\circ} \mathrm{C}$ overnight. The fixed samples were made into cryostat blocks by freezing them on to cork mats and $5 \mu \mathrm{m}$ thick sections were cut at $-20^{\circ} \mathrm{C}$. The sections were picked up on to poly-L-lysine coated glass slides and air dried.

Specimens from six guinea pigs were also frozen in melting Arcton $\left(-150^{\circ} \mathrm{C}\right)$ and freeze dried overnight at $-40^{\circ} \mathrm{C}$. The specimens were then fixed in benzoquinone vapour at $60^{\circ} \mathrm{C}$ for three hours and embedded in paraffin wax. Sections $5 \mu \mathrm{m}$ thick were cut on a Jung microtome.

In order to investigate the complete distribution pattern of the peptide containing nerves, whole mount, stretch preparations of the specimens were also made. These were prepared using benzoquinone fixed tissues. The lumen of the gall bladder or the biliary duct was opened using microscissors and the different layers were removed gently under a dissecting microscope using a pair of fine watchmaker's forceps. The preparation was then placed on a poly-L-lysine coated glass slide and stretched lightly when almost dry.

Tissues from each region were also fixed in $10 \%$ formalin and embedded in paraffin wax. Five micrometre thick sections were cut, dewaxed, and stained with haematoxylin and eosin.

The antisera for immunocytochemistry and radioimmunoassay were raised in New Zealand white rabbits against natural porcine VIP, synthetic substance $P$, synthetic bovine somatostatin, synthetic met-enkephalin, and synthetic amphibian bombesin respectively. The specificities of the antisera are shown in the Table.

The indirect immunofluorescence method of Coons and coworkers ${ }^{23}$ was carried out on the cryostat sections and the peroxidase antiperoxidase (PAP) method of Sternberger ${ }^{24}$ was performed on the dewaxed paraffin sections as previously described. The dilutions of the primary antisera are shown in the Table.

The whole mount, stretch preparations were pretreated by dehydration and rehydration through graded alcohols and xylene and by soaking in $0.2 \%$ Triton X-100 in PBS for one hour. ${ }^{25}$ All preparations were incubated with primary antiserum for 24 hours at $4^{\circ} \mathrm{C}$. They were then washed in PBS three times, 10 minutes each, and incubated with the second layer antiserum, fluorescein isothiocyanate conjugated goat anti-rabbit globulin (1:100 in PBS) for four hours at room termpature. After washing as before, the preparations were mounted in PBS/ glycerine (1:9) and examined under a Reichert-Jung Polyvar widefield photomicroscope equipped with bright field, dark field, phase contrast, and ultraviolet light source.

The controls for immunostaining included preabsorption of the primary antisera with appropriate antigens (Table), the use of normal rabbit serum as first layer in place of a primary antiserum, and omission of the first layer.

For radioimmunoassay, a representative piece of tissue was removed from each region, plunged into boiling acetic acid $(0.5 \mathrm{M})(5 \mathrm{ml} / \mathrm{g}$ tissue $)$ and maintained at $100^{\circ} \mathrm{C}$ for 10 minutes. Ten and $1 \mu \mathrm{l}$ aliquots of extract solutions were assayed in duplicate for VIP, substance P, somatostatin, and bombesin. Details of the antibodies for radioimmunoassay are shown in the Table.

\section{Results}

Using the method of immunocytochemistry, networks of nerves containing VIP-, substance P-, somatostatin-, and met-enkephalin-like immunoreactive material were found in nearly all the regions of the gall bladder and the biliary pathways, in both the whole mount stretch preparations and the tissue sections. Bombesin immunoreactive nerves were

Table Details of antisera

\begin{tabular}{|c|c|c|c|c|c|}
\hline \multirow{2}{*}{$\begin{array}{l}\text { Antiserum } \\
\text { raised against }\end{array}$} & \multirow{2}{*}{$\begin{array}{l}\text { Region } \\
\text { specificity }\end{array}$} & \multicolumn{3}{|c|}{ Dilution } & \multirow{2}{*}{$\begin{array}{l}\text { Concentration of peptides } \\
\text { used for absorption and } \\
\text { abolishing staining* }\end{array}$} \\
\hline & & $I F$ & $P A P$ & $R I A$ & \\
\hline VIP & Middle-C terminal & $1 / 2000$ & $1 / 20000$ & $1 / 400000$ & $0 \cdot 1$ \\
\hline Substance $P$ & Whole molecule & $1 / 1000$ & $1 / 10000$ & $1 / 8000$ & 2 \\
\hline Met-enkephalin & C terminal & $1 / 500$ & $1 / 5000$ & - & 1 \\
\hline Somatostatin & Whole molecule & $1 / 2000$ & $1 / 10000$ & $1 / 240000$ & 1 \\
\hline Bombesin & C terminal & $1 / 2000$ & $1 / 20000$ & $1 / 640000$ & 1 \\
\hline
\end{tabular}

* nmol/ml diluted antiserum.

Cross reactivity of antisera to substance $P$ and bombesin has been tested with cross preabsorption controls - that is, incubate bombesin antigen with substance $P$ antiserum and vice versa before the immunostaining. The positive immunostaining results established the non-cross reactivity of these two peptide antisera. This has been further confirmed by their distinct concentrations and distributions in the investigated tissue. 
mainly seen in the sphincters. The abundance and the arrangement of the immunostained nerves were shown more clearly in the whole mount, stretch preparations than in the sections. Each of the five types of immunostained nerves seemed to have its own characteristic distribution pattern. Among them, VIP- and substance P-like immunoreactive nerves appeared to be the most abundant in most of the regions $(11 \pm 1.5 \mathrm{pmol} \mathrm{VIP} / \mathrm{g}$ wet weight of tissue, mean \pm SEM, in the sphincter; $21 \cdot 5 \pm 1.8$ pmol substance $\mathrm{P} / \mathrm{g}$ in the common bile duct). Nerves containing somatostatin and metenkephalin-like immunoreactivities were much sparser and, sometimes, could be seen only in the whole mount stretch preparations. This was reflected by the low level of somatostatin immunoreactivity found by radioimmunoassay in the gall bladder; $1 \cdot 8 \pm 0 \cdot 2 \mathrm{pmol} / \mathrm{g}$. Densely packed bombesin-like immunoreactive nerves were mainly found in the region of the sphincter, where the mean concentration of bombesin immunoreactivity was $14 \cdot 6 \pm 2 \mathrm{pmol} / \mathrm{g}$. All the controls for immunocytochemistry were negative.

Vasoactive intestinal polypeptide- and substance P-like immunoreactive nerves were predominantly localised in the ganglionated plexus and the mucosal plexus (Figs 1 and 2), and a few VIP- and substance P-like immunoreactive cell bodies were sometimes observed in the ganglionated plexus (Figs 2 and 3 ). The immunostained nerve fibres were often seen forming dense, mesh-like structures and surrounding ganglion cells which showed no immunoreactivity to the antisera (Figs 4 and 5). Single or bundles of VIP- and substance P-like immunoreactive nerves were also commonly found running along the connecting strands formed by the nerve bundles linking separate groups of one to four neuronal cell bodies. Vasoactive intestinal polypeptide and substance P-like immunoreactive nerves

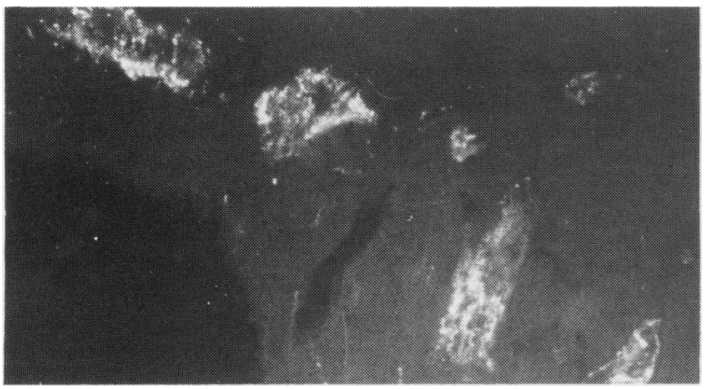

Fig. 1 Substance $P$ immunoreactive nerves in ganglionated plexus of gall bladder. (Indirect immunofluorescence (IF) method.) $(\times 250$, original magnification. $)$

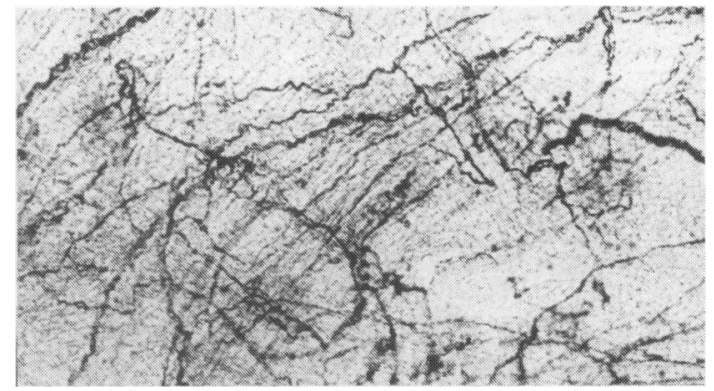

Fig. 2 Networks of VIP immunoreactive nerves in ganglionated plexus of gall bladder. (Whole mount stretch preparation, PAP method.) ( $\times 800$, original magnification.)

formed randomly arranged networks with numerous varicosities which were uniform in size with occasional larger spindle-shaped ones. These nerves were also frequently found surrounding blood vessels, particularly arteries, in all layers.

Somatostatin- and met-enkephalin-like immunoreactive nerves, although more sparse, had similar distribution patterns to those containing VIP and substance $P$ - that is, they were also found mainly in the plexus (Fig. 6) and were occasionally seen in the lamina propria. They were not, however, found to be associated with blood vessels. No met-enkephalin or somatostain immunoreactive neuronal cell bodies were found.

The muscle layer of the gall bladder, cystic duct, and hepatic duct were only sparsely innervated by different peptide immunoreactive nerves. The density of these nerves gradually increased as the muscle layer of the common bile duct reached the sphincter and became thicker.

In the sphincters, which included the sphincter of the common bile duct, the ampulla, and the

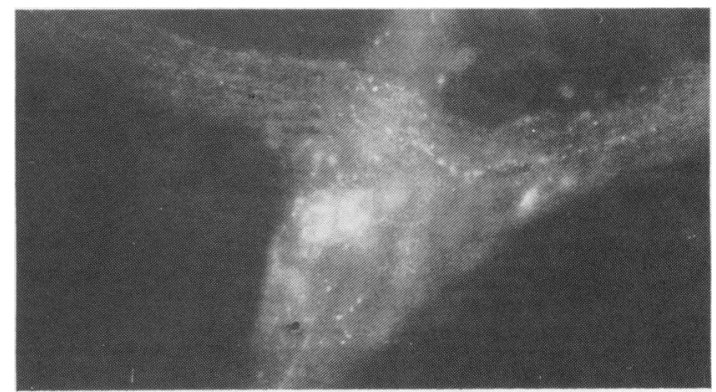

Fig. 3 Substance P immunoreactive neuronal cell bodies in ganglionated plexus of gall bldder. (Whole mount stretch preparation, IF method.) ( $\times 700$, original magnification.) 


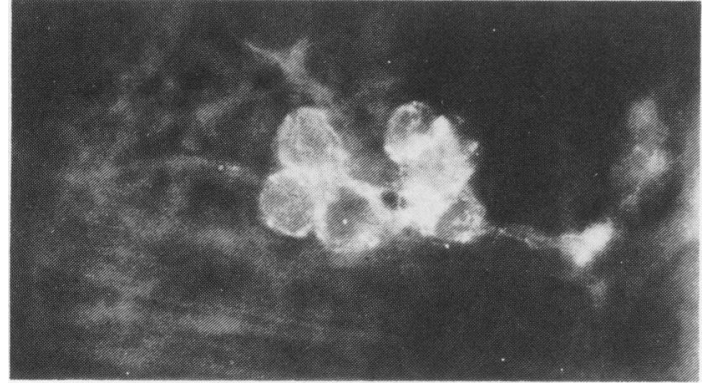

Fig. 4 VIP immunoreactive varicose nerve fibres surrounding some neurones which do not contain the peptide. (Stretch preparation, IF method.) $(\times 1000$, original magnification.)

sphincter of papilla, the distribution patterns of the four types of immunostained nerves and, in addition, bombesin immunoreactive nerves, were essentially similar to those found in the muscle layer of the duodenum. The nearer to the innermost circular muscle the innervation lay, the denser it appeared to be and it was always more dense than that of the duodenal muscle. There were certain distinct differences between the distributions of the five types of immunoreactive nerves in the sphincters. Vasoactive intestinal polypeptide immunoreactive nerves were concentrated not only in the muscle bundles (Fig. 7) but also densely distributed in the myenteric and the submucous plexuses. Met-enkephalin and bombesin immunoreactive nerve fibres, on the other hand, were distributed mainly among the muscle cells (Figs 8 and 9). Somatostatin immunoreactive nerves were the most scarce of all and, in certain sections, none could be found. When present, somatostatin

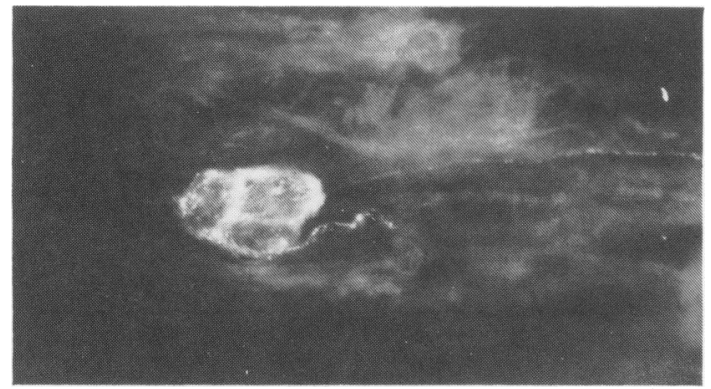

Fig. 5 Substance P immunoreactive varicose nerve fibres surrounding some neurones which do not contain the peptide. (Stretch preparation, IF method.) ( $\times 1000$, original magnification.)

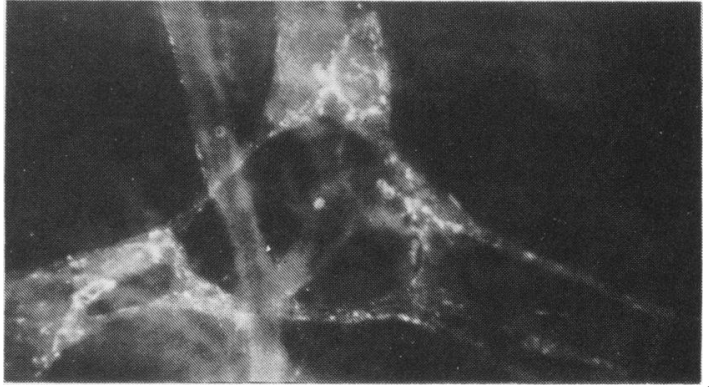

Fig. 6 Nerves containing somatostatin immunoreactivity in ganglionated plexus of gall bladder. (Stretch preparation, IF method. $(\times 800$, original magnification. $)$

immunoreactive fibres were seen in the submucous and in the myenteric plexuses, as well as between the muscle cells.

Some substance $\mathrm{P}$ immunoreactive nerves were mainly related to the smooth muscle. Separated somatostatin immunoreactive cells could be observed in the mucosal epithelium of the common bile ducts $(76 \pm 19 \mathrm{pmol} / \mathrm{g})$ and the sphincters $(162 \pm 30 \mathrm{pmol} / \mathrm{g}$ ) (approximately 1.5 cells per $1 \mathrm{~mm}$ length of epithelial mucosa in $5 \mu$ thick section) (Fig. 10) but not in the epithelium of the gall bladder. The region most denseley innervated by peptide immunoreactive nerves, particularly VIP immunorective nerves, was the circular muscle of the sphincter of the duodenal papilla. In this area, a few VIP immunoreactive neurones were occasionally seen, lying outside the muscular ring of the duodenal papilla.

The results obtained using radioimmunoassay, for the concentrations of extractable VIP, substance $P$,

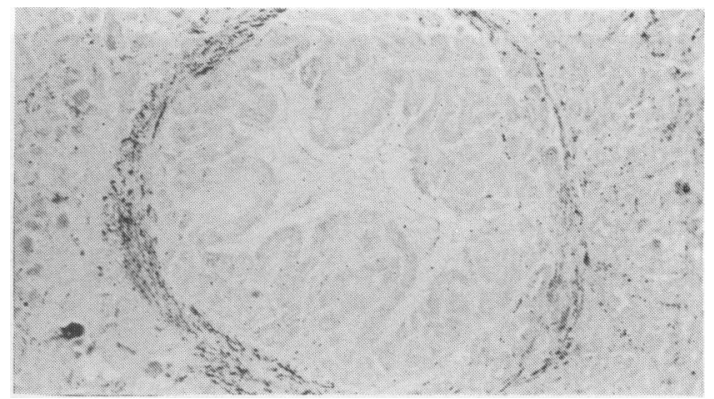

Fig. 7 Dense VIP immunoreactive nerve fibres in smooth muscle of the sphincter of Oddi. (IF method.) $(\times 80$, original magnification.) 


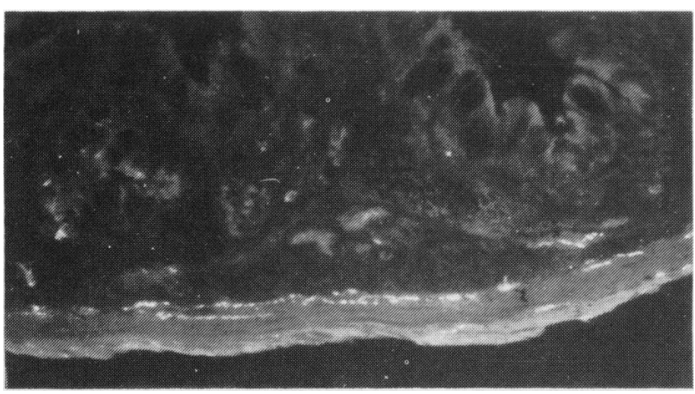

Fig. 8 Met-enkephalin immunoreactive nerves in the muscle layer of the common bile duct adjacent to the sphincter of Oddi. (IF method.) $(\times 400$, original magnification.)

somatostatin, and bombesin (Figs 11-14) were largely in agreement with the density and distribution of each type of peptide containing nerve and cells as shown by immunocytochemistry. For example, high concentrations of somatostatin were detected by radioimmunoassay in the regions of the common bile duct and the sphincters, where immunocytochemistry showed, in addition to a few somatostatin immunoreactive nerves, a number of epithelial cells containing somatostatin immunoreactivity.

\section{Discussion}

We have shown here that VIP, substance $P$, somatostatin, and met-enkephalin immunoreactive nerves are present in the gall bladder and the biliary pathways of the guinea pig. Bombesin immunoreactive nerves were found only in the region of the sphincters. Our results showed that the peptide

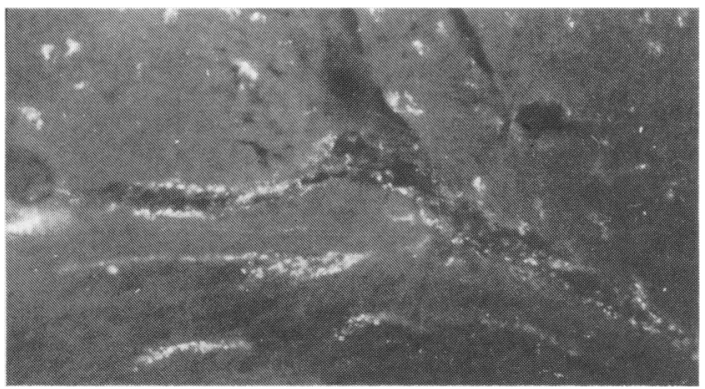

Fig. 9 Bombesin immunoreactive nerves in muscle layer of sphincter of Oddi. (IF method.) ( $\times 600$, original magnification.)

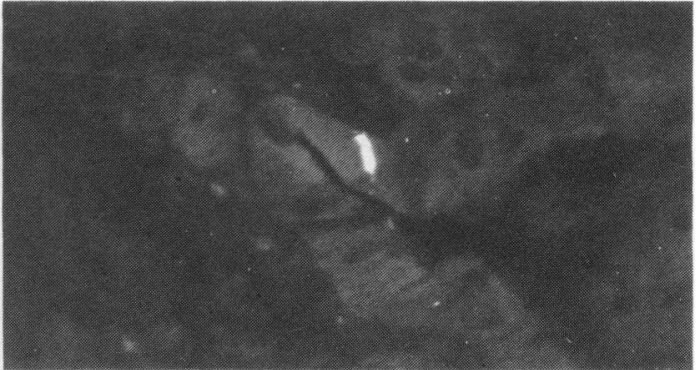

Fig. 10 A somatostatin immunoreactive mucosal cell in common bile duct. (IF method.) $(\times 300$, original magnification.)

immunoreactive nerves of the gall bladder and the biliary pathways possess a pattern similar to that of the gut, ${ }^{16}$ although each type of peptide immunoreactive nerve has its own characteristic distribution. The finding of peptide immunoreactive neuronal cell bodies in the gall bladder is in agreement with previous reports that most peptide immunoreactive nerves in the alimentary tract have an intrinsic origin. ${ }^{15} 1625-27$ As the storage of peptides in the perikarya is often poor, it is possible that the number of observed peptide immunoreactive neurones would be increased if axonal transport blocking agents such as colchicine or vinblastine were used.

The whole mount stretch preparations used in this study were found to give superior results to those obtained using tissue sections when the organs under investigation were poorly innervated - for example, the gall bladder and the bile ducts, where the immunostained nerves were sometimes hardly

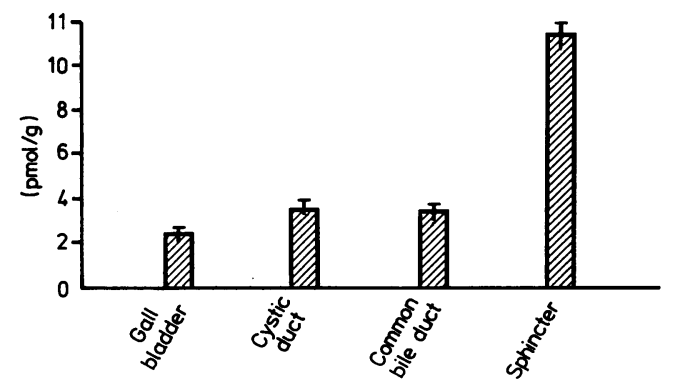

Fig. 11 Extractable VIP in gall bladder and biliary tract of guinea pig. 


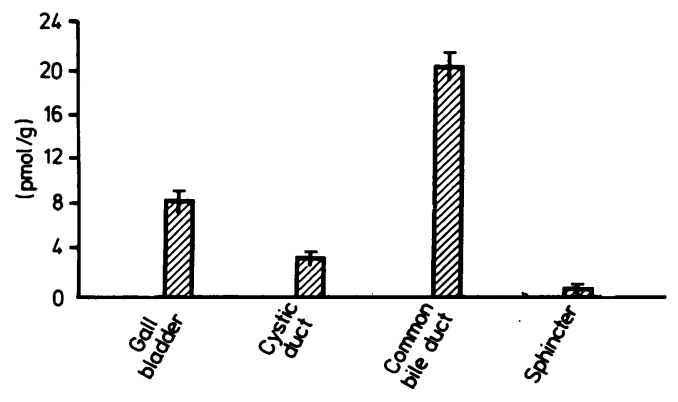

Fig. 12 Extractable substance $P$ in gall bladder and biliary tract of guinea pig.

visible on the tissue sections. In some regions - for example, the sphincter - however, this approach was not feasible.

In a previous investigation, ${ }^{13}$ it has been found that there are three major nerve plexuses in the wall of the gall bladder and the biliary pathways - that is, the mucosal and ganglionated plexuses and a nerve plexus which lies in the adventitia of the cystic artery and its branches. Communications between these plexuses exist. Abundant adrenergic and cholinergic nerves with characteristic distributions have been shown in the gall bladder and the biliary tract.

In the present study, the nerves known to contain the classical neurotransmitters seemed to be mingled with peptide immunoreactive nerves. The distribution patterns of peptide immunoreactive nerve fibres in the gall bladder and the biliary pathways were similar to those found for the adrenergic innervation whereas the peptide

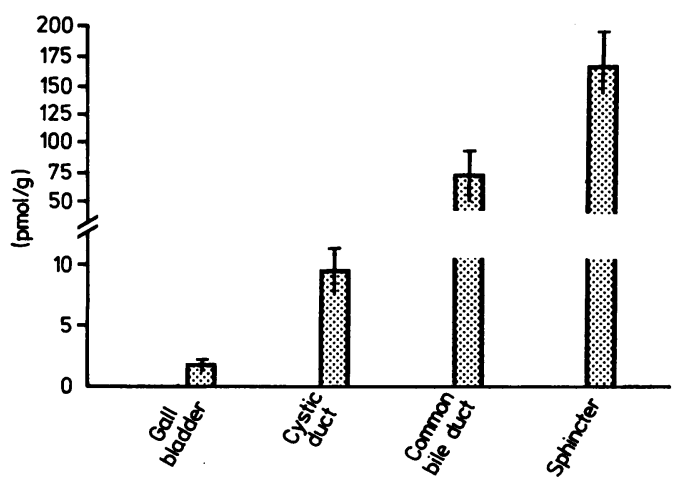

Fig. 13 Extractable somatostatin in gall bladder and biliary tract in guinea pig.

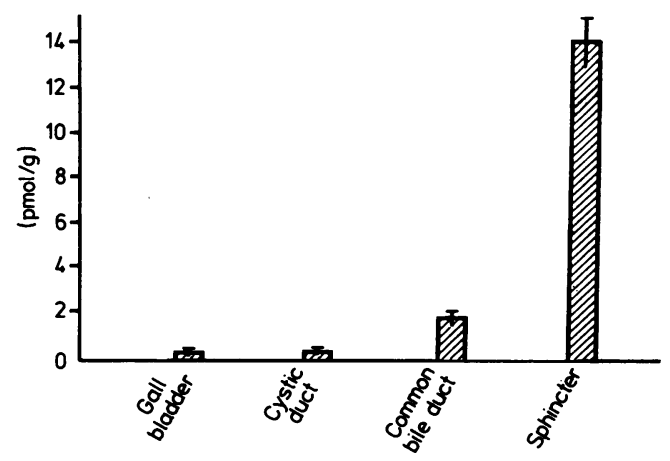

Fig. 14 Extractable bombesin in gall bladder and biliary tract in guinea pig.

immunoreactive nerves in the muscle bundles of the sphincters were similar to the cholinergic innervation as regards their density and distribution pattern. ${ }^{12} 13$ The networks of different types of nerve and the relationships between peptide and non-peptide containing neurones indicate that there is a sophisticated neuronal control system acting upon the gall bladder and the biliary tract.

Many peptides have been reported to have effects on the gall bladder and the biliary tract. ${ }^{28-35}$ Only VIP and met-enkephalin immunoreactive nerves, however, have been reported to be present in these regions. ${ }^{18} 20$ In the gall bladder, VIP has been shown to cause relaxation of the wall and inhibition of secretion. ${ }^{36}$ Vasoactive intestinal polypeptide receptors have also been found in the gall bladder. ${ }^{37}$ Stimulation of vagal nerves led to an increase of VIP concentration in the portal venous and peripheral arterial plasma, indicating that VIP is likely to act as a neurotransmitter. ${ }^{38}{ }^{39}$ In this study, VIP immunoreactive nerves were found to be abundant throughout the regions examined, suggesting that VIP may be one of the major neuronal components in this control system. The occurrence of VIP immunoreactive nerves in the lamina propria, underneath the columnar epithelium of the gall bladder, may be related to the inhibitory effect of VIP on the gall bladder secretion. ${ }^{36}$

Subtance $P$ has been shown to have many physiological and pharmacological effects on various organs including the gall bladder and the bile duct. ${ }^{40}$ It decreases the output of hepatic bile and amylase in a dose dependent manner. It also inhibits the choleresis induced by CCK or VIP. ${ }^{41}$

As in many other organs, the blood vessels in the gall bladder and the bile ducts are often surrounded by VIP and substance P immunoreactive nerves. ${ }^{1626}$ Thus, the local blood flow may also be monitored 
by, in addition to adrenergic and cholinergic nerves, peptidergic ones.

In the present study, somatostatin, metenkephalin and bombesin immunoreactive nerves have also been demonstrated in the gall bladder and the biliary tract. These nerves are less abundant than those containing VIP and substance P immunoreactivities. Somatostatin has been reported to antagonise the effect of CCK on the gall bladder in man, ${ }^{33}$ although, in guinea pig and dog, this effect has been shown to inhibit acetylcholine release from the myenteric plexus of the intestine. ${ }^{42}$ The occurrence of met-enkephalin immunoreactive nerves indicates that such a mechanism may also exist in the gall bladder.

Somatostatin has been shown previously in neuroendocrine cells of the hypothalamus, endocrine cells of the gut and pancreas, as well as in the central and peripheral nervous system. Somatostatin plays a mainly inhibitory role in, for example, endocrine and exocrine secretion, gastric and biliary motility, splanchnic blood flow, intestinal absorption. ${ }^{43}$ The significance of the somatostatin immunoreactive cells found in the biliary tract of the guinea pig remains to be elucidated.

Dr W Cai is a visiting scholar from the Department of Histology and Embryology, Chang Hai Hospital, Shanghai, China. Dr J Gu is a visiting scholar from the Department of Pathology, Peking Medical College, Peking, China. Dr W Huang is a visiting scholar from the Institute of Acupuncture, Academy of Traditional Chinese Medicine, Peking, China.

The authors wish to thank Dr G Gabella for reading this manuscript and for his valuable advice.

\section{References}

1 Sutherland SD. The intrinsic innervation of the gallbladder in Macaca rhesus and Cavia porcellus. J Anat 1966; 100: 261.

2 Sisto L, Robecchi A. Contribution a l'étude l'innervation de la vesicule biliarie. Bull Assoc Anat $53^{\circ}$ Congr 1968; 143: 7.

3 Baumgarten HG, Lange W. Extrinsic adrenergic innervation of the extrahepatic system in guinea-pigs, cats and rhesus monkeys. Z Mikrosk Anat Forsch 1969; 100: 606 .

4 Mori J, Azuma H, Fujiwara M. Adrenergic innervation and receptors in the sphincter of Oddi. Eur J Pharm 1971; 14: 365.

5 Kyösöla K, Rechardt L. Adrenergic innervation of the choledochoduodenal junction of the cat and dog. Histochemistry 1973; 34: 325.
6 Kyösöla K. Cholinesterase histochemistry of the innervation of the smooth muscle sphincters around the terminal intramural part of the ductus choledochus of the dog and cat. Acta Physiol Scand 1974; 90: 278.

7 Kyösöla K. Structure and innervation of the choledochoduodenal junction. Ann Chir Gynaecol suppl 1976; 192: 1.

8 Kyösöla K. Cholinesterase of the gallbladder. Histochemistry 1977; 50: 337.

9 Kyösöla K. Adrenergic and cholinergic innervation of the supraduodenal common bile duct. Am J Gastroenterol 1978; 70: 179.

10 Kyösöla K, Penttila O. Adrenergic innervation of the human gallbladder. Histochemistry 1977; 54: 209.

11 Davison JS, Al-Hassani N, Crowe R, Burnstock G. The non-adrenergic inhibitory innervation of the guinea-pig gallbladder. Eur J Physiol 1978; 377: 43.

12 Onada M, Miyazaki T. The adrenergic and cholinergic innervation of the gallbladder and extrahepatic biliary duct in cat and humans. Nippon Shokakibyo Gakkai Zasshi 1980; 77: 768.

13 Cai W, Gabella G. Innervation of the gallbladder and biliary pathways in the guinea-pig. J Anat 1983; 136: 97.

14 Gabella $G$. Innervation of the gastrointestinal tract. Intern Rev Cytol 1979; 59: 129.

15 Schultzberg M, Hökfelt T, Nilsson G et al. Distribution of peptide- and catecholamine-containing neurons in the gastrointestinal tract of rat and guinea-pig: immunohistochemical studies with antisera to substance $P$, vasoactive intestinal polypeptide, enkephalin, somatostatin, gastrin/cholecystokinin, neurotensin and dopamine B-hydroxylate. Neuroscience 1980; 5: 689.

16 Bishop AE, Ferri G-L, Probert L, Bloom SR, Polak JM. Peptidergic nerves. In: Polak JM, Bloom SR, Wright NA, Daly MJ, eds. Basic science in gastroenterology. Structure of the gut. London: Glaxo, 1982: 221-38.

17 Bloom SR, Polak JM. Gut hormone overview. In: Bloom SR, ed. Gut hormones 1st ed. Edinburgh: Churchill Livingstone, 1978: 3-18.

18 Sundler F, Alumets J, Hakanson R, Ingemanson S, Fahrenkrug J, Schaffalitzky de Muckadell OB. VIP innervation of the gallbladder. Gastroenterology 1977; 72: 1375.

19 Alumets J, Fahrenkrug J, Hakanson R, Sundler F, Chang KJ. A rich nerve supply is characteristic of sphincters. Nature (Lond) 1979; 280: 155.

20 Polak JM, Sullivan SN, Bloom SR, Facer P, Pearse AGE. Enkephalin-like immunoreactivity in the human gastrointestinal tract. Lancet 1977; 1: 972.

21 Heitz PH, Polak JM, Kasper M, Timson CM, Pearse AGE. Immunoelectron cytochemical localization of motilin and substance $P$ in rabbit bile duct enterochromaffin (EC) cells. Histochemistry 1977; 50: 319.

22 Bishop AE, Polak JM, Bloom SR, Pearse AGE. A new universal technique for the immunocytochemical localisation of peptidergic innervation. J Endocrinol 1978; 77: 25.

23 Coons AH, Leduc EH, Connolly JM. Studies on antibody production. J Exp Med 1955; 102: 49.

24 Sternberger LA. The unlabelled antibody enzyme 
method. In: Immunocytochemistry. New Jersey: Prentice-Hall Inc, 1974: 129-71.

25 Hartman BK, Zide D, Adenfriend S. The use of dopamine B-hydroxylase as a marker for the central noradrenergic nervous system in the rat brain. Proc Natl Acad Sci USA 1972; 69: 2722.

26 Polak JM, Bloom SR. Regulatory peptides of the gut, the essential mechanism for gut control. In: Wright $\mathrm{R}$, ed. Recent advances in gastrointestinal pathology. Philadelphia, London, Toronto: Saunders, 1980: 23-46.

27 Costa M, Furness JB, Butta R, Said SI. Distribution of enteric nerve cell bodies and axons showing immunoreactivity for vasoactive intestinal polypeptide in the guinea-pig intestine. Neuroscience 1980; 5: 587.

28 Jessen KR. Removal of the ganglionated plexuses from the gut wall: advantages for studies of the enteric nervous system. In: Polak JM, Bloom SR, Wright NA, Daly MJ, eds. Basic science in gastroenterology. Structure of the gut. London: Glaxo, 1982: 269-80.

29 Lonovics J, Devitt P, Rayford PL, Thompson JC. Actions of VIP, somatostatin and pancreatic polypeptide on gallbladder tension and CCK-stimulated gallbladder contraction in vitro. Surg Forum 1979; 30: 407.

30 Bojornsson OG, Adrian TE, Dawson J et al. Effects of gastrointestinal hormones on fasting gallbladder storage patterns in man. Eur J Clin Invest 1979; 9: 293.

31 Ogoshi K, Tsuyuki A, Mitomi T, Abe O, Abe K, Yanaihara N. Plasma substance $P$ level in patients with hepatic diseases. In: Miyoshi A, Grossman MI, eds. Gut peptides, secretion, function and clinical aspects. Tokyo: Kodansha, 1979: 391-3.

32 Paitras P, Yamada T, Walsh JH. Absence of effect of somatostatin on the guinea-pig gallbladder. Can $J$ Physiol Pharmacol 1980; 58: 179.

33 Nakata K. Effects of C-terminal octapeptide of cholecystokinin and prostaglandins on adrenergic functions in the guinea-pig gallbladder and sphincter of Oddi. Jpn J Pharmacol 1981; 31: 77.

34 Johansson C, Kollberg B, Efendic S, Uvnas-
Wallensten K. Effect of graded doses of somatostatin on gallbladder emptying and pancreatic enzyme output after oral glucal in man. Digestion 1981; 22: 24.

35 Brennan LJ, Mcloughlin TA, Mutt V, Tatemoto K, Wood JR. Effect of PHI, a newly isolated peptide on gallbladder function in the guinea-pig. Progr Physiol Soc 1982; April: 92.

36 Takahashi I, Suzuki T, Aizawa I, Itoh Z. Comparison of gallbladder contractions induced by motilin and CCK in dogs. Gastroenterology 1982; 82: 419.

37 Wood JR, Brennan LJ, Hormbrey JM. Comparison of the effects of VIP, secretin, GIP and glucagon on gall bladder function. Regulatory Peptides 1982; 3: 169.

38 Dupont C, Broyart J-P, Broer Y, Chenut B, Laburthe $M$, Rosselin G. Importance of the vasoactive intestinal peptide receptor in the stimulation of cyclic adenosine $3^{\prime}, 5^{\prime}$-monophosphate in gallbladder epithelial cells of man, comparison with the guinea-pig. J Clin Invest 1981; 67: 742 .

39 Schaffalitzky de Muckadell OB, Fahrenkrug J, Holst JJ. Release of vasoactive intestinal polypeptide by electrical stimulation of vagal nerves. Gastroenterology 1977; 72: 373.

40 Edwards AV, Bloom SR. Recent physiological studies of the alimentary autonomic innervation. In: Polak JM, Bloom SR, Wright NA, Daly MJ, eds. Basic science in gastroenterology. Structure of the gut. London: Glaxo, 1982: 255-67.

41 Powell D, Skrabanek P. Substance P. In: Bloom SR, Polak JM, eds. Gut hormones 2nd ed. Edinburgh: Churchill Livingstone, 1981: 396-401.

42 Magnusson (Holm) I, Thulin L. Effects of substance P on CCK- or VIP-induced choleresis in anaesthetized dog. Acta Physiol Scand 1979; 106: 293.

43 Sakai KK, Hymson DL, Shapiro R. The mode of action of enkephalins in guinea-pig ileum. Neuroscience 1978; 10: 317

44 Patel YC, Yamada T, Walsh JH. Absence of effect of somatostatin on the guinea-pig gallbladder. Can $J$ Physiol Pharmacol 1980; 58: 179. 